\title{
BETWEEN MUSIC AND TECHNOLOGY: EXISTENCE AND FUNCTIONING CONDITIONS OF THE BRAZILIAN PHONOGRAPHIC INDUSTRY IN THE $21^{\text {sT }}$ CENTURY
}

\author{
Daniel Ferreira Wainer
}

\begin{abstract}
This paper discusses the digitalization process of the Brazilian music industry through bibliographical, documental and empirical sources - the latter based on fieldwork and personal interviews conducted from July 2014 to June 2015. To achieve this goal, I intend to: highlight the conditions that lead to the emergence of the digital age; analyze the development of medias, devices and equipment which may have led to this turning point; investigate the possibilities of music production and distribution in the Brazilian context; cross the local circuits of piracy and the independent ways of commercialization, including digital distribution and the copyright issue. The hypothesis raised at the end of this research is that the existence and functioning of the current phonographic industry is pervaded by ruptures and continuities. Finally, I hope that this paper may bring new perspectives about the relationship between music, culture, communication and technology in the Brazilian contemporary context. Particularly, based on empirical research, I reflect upon the effects, ruptures and continuities observed in the current context of digitalization.
\end{abstract}

\section{Keywords}

Copyrights; digitalization; musical production; phonographic industry; piracy

\section{Resumo}

Este artigo se propõe a discutir, por meio de material bibliográfico, documental e empírico - este último baseado em trabalho de campo e entrevistas pessoais realizadas entre julho de 2014 e junho de 2015 -, o processo de digitalização da indústria fonográfica brasileira. Para cumprir este objetivo, busca-se: observar as condições que marcam o advento da era digital; analisar a história de desenvolvimento das mídias, dispositivos e equipamentos que teriam levado a essa inflexão do mercado de discos; investigar as possibilidades de produção e distribuição musical no contexto brasileiro; percorrer os circuitos locais da pirataria, os caminhos independentes, as formas de distribuição digital e a questão dos direitos autorais. A hipótese que emerge ao final dessa empreitada é a de que a existência e o funcionamento da indústria fonográfica atual se encontram em uma trilha permeada por rupturas e continuidades. Espera-se, enfim, que esta pesquisa possa trazer novos olhares sobre as relações entre música, cultura, comunicação e tecnologia no Brasil contemporâneo. Em particular, com base numa investigação empírica, o autor reflete sobre os efeitos, as ruturas e as continuidades observados no contexto atual de digitalização.

\section{Palavras-chave}

Digitalização; direitos autorais; indústria fonográfica; pirataria; produção musical 


\section{INTRODUCTION}

This paper aims to present some of the operative characteristics in the Brazilian Phonographic Industry from the 1980's up until today. It critically shows how the transformations that happened in the segment are related to an ever growing digitalization process in the cultural and artistic lives. In order to fulfill this plan, I will initially consider the conditions that mark the beginning of the digital era, following some clues by a few authors (Campanelli, 2012; Noronha e Sousa, Zagalo \& Martins, 2012; Piñeiro-Otero \& Ribeiro, 2015). On a sequence, I evaluate the historical process of medias, gadgets and equipment developing that would have led to such an inflection in the music business, which tends to put the industry's technicality as a path, bringing back an analytical movement that I have already previously made (Wainer, 2016a).

This argumentation's outline aims to offer foundations to examine the field that comprehends the Brazilian phonographic industry in the turn of the century, which suggests a revision of the possibilities in producing and distributing music in the country. The piracy circuits, the independent paths, the ways of digital distributing and copyrights will also be looked at through a method that fundaments itself in analyzing bibliographic and documental material. This article also presents empirical data from fieldwork and interviews held in Rio de Janeiro, between July 2014 and June 2015, with musicians, producers, arrangers and managers in the national music business.

\section{MEDIAS, GADGETS AND EQUIPMENT IN THE MUSIC BUSINESS DIGITALIZATION}

\section{THE DIGITAL CONTEXT}

According to Campanelli (2012), art stops being a mere object, in the contemporary digital context, and becomes an actual relation network. The concept of intervention, in this sense, acquires an importance in the same way that the practice of do it yourself does, or, as the author prefers it, remix it yourself. Such ponderings come from the following question: to what extent do the technologies permit people's new creative existences? In the proposed field of analysis, the digital context is the bricolage context, the context of flux, of the breaking of resistances and borders, of hybridity and the end of some distinctions between eminently amateur or professional boundaries. This might cause the daily practices to start referring to people's capacity to deal with the massive amount of information that becomes accessible through more accurate tools.

By a similar means, Amaral (2012) and Noronha e Sousa, Zagalo and Martins (2012) show that the communicative practices are being transformed, especially where the relationship between producers and consumers in the mediatic universe is concerned. The democratization of the digital medias and its network connection have actually made the public interact in an active way, producing interpretations, appropriations and becoming, in the authors' language, "a story spreading agent" (Noronha e Sousa et al., 2012, p. 167). What are the participative potentialities that the digital technologies have been offering? How does the nature of narratives transform itself and the relation between producers and consumers in the digital era? 
Piñeiro-Otero and Ribeiro's work (2015) tries to answer some of these questions when it scrutinizes processes of inclusion of Spanish and Portuguese radios in digital and online environments. In other words, the authors explicit the question of mobility in the digital contemporary era while analyzing the transposition of traditional communication means into mobile delivery platforms. The apps that make this kind of interface have been producing, for instance, new ways of relating themselves to the audiences as well as a convergence of interactive contents shared among listeners-users. In this process, smartphones, as well as other mobile devices, end up transforming the radio broadcasting experience into something more dynamic, mostly because of platform mobility.

The mobility theme is also featured in Ganguin and Hoblitz (2012), authors that try to identify creative means of using cellphones through a comparison between users that play games in these devices or not. Is there a correlation between innovative means of communication and the users that play more or play less? In the cited article the differences between smartphones and cellphones are posited, as well as the possibility of media convergence and app usage. The cell phone seems to emerge as the main symbol of mobility and a metaphor of contemporary ubiquity, which follows the researches by Herschmann (2010) about the transformations in the contemporary musical industry that increasingly acts by and amongst these devices.

The aforementioned researches bring to consideration some elements that allow the conditions of existence and the functioning of a broad universe to be thought through. Noronha e Sousa et al. (2012) even address more thoroughly the "digital" category in itself, based in other authors who study the topic. In order to better comprehend the relations established between digitalization and the more specific context of musical industry, however, I am grounded in Vicente's considerations (1996) about the impact of certain technical transformations in the ways in which the western world produces and broadcasts music. In doing so, I am suggesting that the industrial production of music is in the constantly moving territory of technologies and in the territory of the broader functioning of a capitalist system that constantly searches for technical improvement.

\section{TECHNICAL MEANS AND MUSICAL PRODUCTION}

Vicente (1996, p. 2) points out that the technological developments of the production and distribution of popular music in the West can be arranged in four main phases such as the mechanical, the electrical, the electronic and the digital. Authors like Abreu (2009), on the other hand, establish that the industrial revolution in the communication technologies actually starts still halfway through the $19^{\text {th }}$ century, with the invention and development of the telegraph. As a consequence of applying this technology, the number and the speed of communication have multiplied in such a broad manner that new researches have started, intending to register and reproduce sound.

In order to shed some light on phonographic industry's digitalization, while following the tracks of Vicente (1996), one need to go through a sociotechnical reality produced by electronic hardwares and softwares. Nevertheless, how can we formalize a distinction 
between the digital context and the preceding reality, which had been based on a production that uses analogical apparatuses? To explicit such a difference, I remember that sound, according to Aurélios' dictionary, is an "acoustic phenomenon that consists in propagating sound waves by a body that vibrates in an elastic material environment", especially air. As a consequence, the "analogical recording processes are those in which the characteristics of a sound wave are represented, by an analogy, through the fluctuations on an electromagnetic field" (Vicente, 1996, p. 31).

As an example, one can refer to the vibrations provoked on the air by a singer's voice, "converted through a microphone into variations of an electric potential and thus stored in a magnetic tape" (Vicente, 1996, p. 31). In order to reproduce the sound, "the tape is played and its signals are amplified and addressed to a speaker, where they are transformed into the vibrations of a cardboard cone" (Vicente, 1996, p. 32). The transmission of these vibrations through the air, finally, reproduces the sound, which is significantly different from the procedure that characterizes a digital system of audio production. In this one, "the sound wave is subdivided into samples and each one of them is mathematically located in the wave's space and time" (Vicente, 1996, p. 32). As if it were a film projection, the movement sensation is given by the frequency with which the samples are transmitted, and, to summarize, it is this distinction that allows us to, at least minimally as well as formally, understand how these universes work.

In fact, the digitalizing process of music was formed throughout the $20^{\text {th }}$ century with the emergence, development and usage of equipment, gadgets, devices, programs and protocols - hardwares as well as softwares - which have ultimately virtualized the musical production in a broader sense. This equipment is characterized mostly by allowing a wide manipulation of the characteristics of the captured sound; especially of the height, volume, tone and shape of the sound waves.

Some of the devices that emerge in this context are the samplers, the synthesizers, the drum machines, the sequencers, the multi-tonal modulators, the digital recorders, the effects modules, the arranger softwares and the digital audio workstations (DAWs), all hardwares and softwares that start to proliferate in music studios since the 1980's. In order to better understand the emergence of these gadgets, it is necessary to return to the technical transformations that take place still in the end of $19^{\text {th }}$ century. Thus I specifically go back to the history that reports the development of synthesizers and also of transistors, both fundamental elements for a broader comprehension of the phase we are looking at.

According to the specific literature on the subject, "the first synthesized sounds generator ever heard of was invented by the north American Thadeus Cahill and had its patent registered still in 1897" (Vicente, 1996, p. 34). Therefore, it was created less than ten years after the beginning of the commercialization of Edison's phonograph, conceived in 1877 and bought by North American Company in 1888. Vicente (1996, p. 34) states that the first three decades of the $2 \mathrm{O}^{\text {th }}$ century show a series of technological developments in this same area, namely of devices capable of synthesizing sounds, such as the Thérémin or the Aetherophone - invented by Leo Thérémin in 1924-, the Sphärophon 
and the Dynaphone in 1927 -, the Ondes Musicales or Ondes Martenot, in 1928 and the Trautonium - in 1930.

This equipment was still monophonic, which means that they only reproduced one sound at a time, from manual controlling, and were capable of altering the frequency, the volume and the tone of the produced audio. As a complement, the creation of the polyphonic Givelet, in 1929, renamed in 1935 as Hammond; of the Wurlitzer, in the same decade; and of the electric guitar, such as the development of the first electric piano, the Harold Rhodes, in 1943, attest that the sound synthesizers, which are fundamental in the digital music production era, have existed for a very long time.

After the development of transistors, however, they were enhanced and started to work increasingly through programming resources. In short, it is important to notice that these instruments functioned through oscillators used to generate sound waves, components that were also able to alter the characteristics of the generated wave (Vicente, 1996, p. 35). The synthesizers started being broadly used by the musical industry, in fact, since the mid-1960's, although they could not be considered, at that time, actual digital devices.

The phonographic production practice is then characterized by the following dynamics: the musicians are separated by partitions inside the recording room and use headphones to follow each other's performances. The recording is done in acoustically dry studios and many isolated microphones are used as a means to maximize the separation between the instrumentalists during the session. The engineer actively participates in the sound balance adjustment, selecting the volumes and positioning each instrument in the stereo spectrum - the two channels of sound output. Furthermore, they seek to control the artificial reverb level in the recording, which makes it fundamental to carefully select, place and balance the microphones (Théberge, 1989).

The described work routine can be already seen in a very specific phase of popular music production, called electronic by Vicente $(1996$, p. 3$)$. In this period, an enhancement of the high fidelity techniques is observed, as well as a development of the recorders, which leads to the rise of multichannel studios. The transistors, as already mentioned, are another basic element that explains the strengthening of this phase, since they act as electronic components responsible for amplifying or interrupting electric signals. In practical terms, this technical development of the studios produces a radical separation of the participants in the musical performance. Starting at this point, each of the musicians records his own part after hearing the register of a precedent performance. There is, in this sense, an overlay of instrumental performances and, thus, the act of recording becomes increasingly planned (Théberge, 1989; Vicente, 1996, 2002).

Going back to the synthesizers matter, it is important to emphasize that until the end of the 1970's these devices were still analogical, since they could only reproduce sounds that already existed, analogously synthesizing their sound waves. The future digital synthesizers, on the other hand, would be able to produce their own sounds from digitalized samples of real sounds, which means that, differently from the analogical synthesizers, they could take the place of many instruments in the recording session. They 
were not, as the previous ones, limited to the status of new sound generators (Vicente, 1996, p. 36).

In this paper, I do not pretend to rank each one of the fundamental devices for the digitally made music production. Thus, I will only make a few other considerations about the transformations in the phonographic field starting from the mid 1980's, when the digital tools were widely used and characterized the production of music in studios. Indeed, in that decade, one can observe the developments which culminate in the elaboration of recording and audio reproducing equipment, such as the compact discs (CD's) and the multimedia boards, as well as the establishment of the musical instrument digital interface (MIDI) protocol.

With regards to the $C D$, it is sufficient to say that it is a digital reproduction support made in aluminum, smaller and lighter than a 45 r.p.m. record and a long play (LP), and that it can accommodate approximately 70 minutes of music. In what concerns the MIDI, it is necessary to remark that this new interface has been produced since the development and commercializing of digital samplers, which makes it strictly oriented to instruments that are also digital. With the emergence of this protocol a whole new array of hardwares and softwares has appeared, and, to a large extent, most of the activities in musical production have been virtualized (Vicente, 1996, p. 3).

In the turn of the 1980's to the 1990's, the computer starts to play a fundamental role in the industry's functioning - especially in the 1990's, when the first digital multitrack recorders appear in the market. They were equipped with audio editing widgets, aiming at non-professional consumers. The hardware and software improvements of the computing systems also enable the personal computers (PC's) to start working as digital audio workstations (DAW's), a sort of virtual studio able to record, edit and reproduce sound. In this sense, these machines transform themselves in digital recorders or, more broadly, in actual studios, working in an articulate fashion with other devices thanks to the MIDI protocol (Abreu, 2009).

In this context, it is also possible to identify a production and technology outsourcing, which is to become clearer in the pages to follow. Later in the decade will appear some digital files whose main goal is to facilitate the exchange of information in a network level. The MPEG 1 Layer-3 (MP3) - created by moving picture experts group (MPEG) in 1995 -, a compact file able to transfer data, appears almost at the same time of Napster, a network file share software that comes up in 1999. The music commerce around the world expands through virtual means from mechanisms such as the peer-to-peer $\left(P_{2} P\right)$ protocol, which causes the consumption to be carried out directly online, while not regulated. The recorded sound starts to be a kind of information that can be transferable through digital supports, making the physical phonogram more a cultural symbol than an objective need. 


\section{THE BRAZILIAN PHONOGRAPHIC INDUSTRY IN THE TURN OF THE CENTURY}

\section{PRODUCTION AND DISTRIBUTION CONDITIONS}

The comments above are important to form a better understanding of the functioning of the record business in Brazil from the mid 1990's onwards. After all, this is the moment when the phonographic sector gets deeply in the analyzed universe. The strategy followed by the large multinational companies, up until then, was based not only on the unilateral offer resulting from the top-down mechanism of mass communication, but also on the fact that they practically had the monopoly of the needed resources to make mass musical production. Noronha e Sousa et al. (2012) remind that the traditional communication paradigm always tended to put public in a more passive position, although its will also influenced the choices made by large companies, e.g. the audience studies.

With the increasing digitalization, however, the phonographic scenery starts to be seen in a new light. The 1980's actually was quite difficult for the record industry in the world (Dias, 1997), in such a way that the Brazilian market would only grow again after 1989, when the sales rates reach a historical record. Even taking this into account, the 1990's decade start the same way that the previous one had started, in the midst of a huge retraction in the country's economy. Brazil is then dominated by the political and financial instability related to Fernando Collor de Mello's government (1990-1992) and some of its economical practices, such as the savings seizure - which had affected the population's purchase power. The sales drop generates conservatism in the management of the large phonographic companies, which were characterized by cuts in costs and expenses (Vicente, 2002, p. 143).

In the midst of these processes, in 1990 arises the Music Television Brazil (MTV Brazil) channel, a concession acquired by Grupo Abril. With this novelty, a big step is made towards the production of national video clips, which allowed the usage of new means for divulging the artists. With regard to material dissemination, it is fundamental to highlight some other news in the radio-broadcasting segment. The 1990's witnesses the emerging of many community and pirate stations, as well as a new form of transmission on behalf of the AM and FM radio companies: the satellite transmission. Before that, the AM channels were able to establish national networks with stations that were linked through the transmission of their telephone signal; however, since they needed a better quality audio, FM's could not do the same. It is the first time, then, that the corporations of this segment are able to act on a national coverage, which contributed significantly to the expansion of the music business in the country (Vicente, 2002, p. 152).

It is also important to emphasize that the growth rhythm of the companies linked to the record-producing sector will be restored only in 1993 and this stability will last until 1997. In this year, the sales of material supports overcame the mark of 100 million units, until a new drop came in 1998, resulting from rate depreciation. What can be specially verified in this decade is the end of a process of economic concentration and industry denationalization, which had started in the 1960's and unfolded in the following decades. This process was responsible for, among other things, the onset of some breaches in the phonographic business. Many professionals end up leaving large companies and 
starting their own labels, while the record multinationals firms finally buy some of the large national ones, which also go through fusion processes themselves (Dias 2010, p. 3; Vicente, 2002, p. 272).

As for the main genres divulged, the moment asked for continuity and consolidation, which can be observed in the expansion of a more popular market, especially through Brazilian country music, known as sertanejo. Dias (1997) reminds how rare are the artists that have the privilege of working on their own ideas on a transnational company in the 1990's, due to the prevalence of the standardizing and patterning. On the other hand, a series of autonomous circuits take place, like the alternative rock, the mangue beat, the hip-hop, the carioca funk, the axé music and the electrified forró of Fortaleza, which have contributed to the realization that, even though there was a continuity movement, at this moment comes up "a large group of independent artists" throughout the country, which "have been promoting an extraordinary diversity in the music produced" (Vicente, 2002, p. 278).

With regards to rationalizing activities, the outsourcing becomes accelerated: the record pressing, generally speaking, starts to be done by only three large factories and distributors linked to the multinationals. At the same time, these labels start to withdraw from musical production activities. As an example, there is the EMI enterprise, which sells its studios' in Rio de Janeiro and even declares that the department has ceased to be "the company's business" (Vicente, 2002, p. 144). After all, an open system of production similar to the one developed in the central countries seems to consolidate in Brazil: transnational labels associate with independent labels collaborating with the dissemination and distribution of their productions (Dias, 2010; Vicente, 2002).

The phonographic industry acquires a planetary status, in consonance with the mentioned overture strategy as well as with the globalization phenomenon. Vicente (2002, p. 154) evokes a story by the Backstage magazine in 1994 which makes clearly explicit the change in the industry's production method.

Outsourcing is the keyword when we talk about studios and labels. Twenty years ago this picture might have seemed insane, considering the equipment's high price. However, the prices are lower, the studios multiplied and, consequently, so did the chances of accessing a recording. The closing of large label's studios started because of directives from head offices overseas. Warner Music, which has been in Brazil for 15 years, didn't even get its own studio. The Brazilian EMI once had three top-notch studios, but has now opted for outsourcing. BMG-Ariola has found a different solution for its three studios: they were passed on to the technicians, who provide services to BMG when necessary. Only the large studios of London, Los

\footnotetext{
'According to the entrepreneur Miguel Barcelar, a partner with whom I have talked in fieldwork done for my masters' thesis, "in the past, the labels had their own studios, but the musicians didn't have a home studio (...). This is not like today, anyone in a bedroom can set up a business with an excellent quality". After all, "now, all labels are mere distributors, like in the film industry". Following the same direction, the musician and producer Marcos Valle - another one interviewed by me - would say that, nowadays, he still records in large studios, such as the one owned by Companhia dos Técnicos, in Copacabana neighborhood, Rio de Janeiro, although, in his words, "those enormous ones", from the past, "do not exist anymore". (Wainer, 2016a).
} 
Angeles and New York based labels (...) split the market with several home and private studios. (Vicente, 2002, p. 154)

Once the independent musical production was already a national reality at the turn of the 1980's, it is only in the 1990's that it gets incorporated into the greater industry "with the mission of prospecting, forming and recording new artists" (Vicente, 2002, p. 155). From then on, this kind of production is indeed in a much better quality than it was 15 years before, when the word "independent" was almost a synonym to "handcrafted". The relationship between indies and majors ${ }^{2}$ becomes more than common, because, as the previous decade demonstrated (Fenerick, 2004), the biggest problem for them had always been distributing, something that could be finally overcomed by acting jointly.

In the 1990's, moreover, a new "market ecology" is formed, in which the independent way of producing complements the action done by the majors, through the creation of new artists and elaboration of actions in more specialized niches, which respond to segments whose needs were not yet met by the major labels (Vicente, 2002). Naturally, this phenomenon did not occur only as a result of technological factors, but also due to the many transformations that took place in the phonographic business along the previous years - one aspect that can be emphasized is the broadening of the segmenting, standardization and rationalization procedures in the productions, which became increasingly pasteurized, in order to meet the international market.

After all, the industry crises during the 1980's and early 1990's have made genres like sertanejo and romantic pop remain privileged in detriment of others like rock and música popular brasileira (MPB), discredited by the big labels.

\section{Piracy, INDEPENDENT CIRCUITS, STREAMING ${ }^{3}$ AND COPYRIghtS}

In the late 1990's, an unprecedented crisis has plagued the Brazilian phonographic industry. The proliferation of $\mathrm{CD}$ piracy, $\mathrm{MP}_{3}$ file sharing, defaults and saturation of popular segments such as axé and pagode were just some of the factors responsible for this undermining (Vicente, 2002, p. 195). According to Dias (2010, p. 7), the major industry could not use the pirates to their favor, choosing to fight rather than working with them in benefit of its interests. In this period, the phonogram reproducibility reaches for the first time a global scale, following the same digitalization that now contributed to the growth and expanding of piracy, mostly through CD's. The singer Viviane Godoi, for instance, in an interview, even remembered that:

the LP was a product that you couldn't clone. Also, there was not anything where you could record. DVD's, CD's, nothing existed. There were cassette tapes (...). You could even own a cassette, but (...) It was really difficult to

\footnotetext{
${ }^{2}$ Christiansen (1995), Dias (2000), Hesmondhalgh (1996), Paiano (1994) and Vicente $(2002,2008)$ are some of the authors that study the relations between the independent and major labels.

3 The streaming, also called media flux, is a way of transmitting data via the internet. YouTube and Spotify are two of the main sites that work through this reproduction method.
} 
clone (...). There were no devices that recorded from a device into another.

(Interview to Viviane Godoi)

According to her, "Sony itself was the company that issued the recorder that copied another. They shot themselves in the foot". The movement of "taking out the LP to put on the CD", as Godoi remembers it, "is also gone. My car comes without a CD player, there is only a pen drive slot". Indeed, the conclusion is that "generally, the record sales dropped considerably", for we are, without any doubt, facing another moment: "you turn on the radio... There is no more of that thing that you turn on the radio and listen to everyone (...). It stopped being a vehicle to sell records because records don't sell anymore".

In order to better accommodate the new configuration of the business in the turn of the century, I underline the iconic case of a band that, in the mid 1990's, became notorious coming from outside of the mainstream phonographic production circuit: the Calypso group 4 .

Originally from Belém do Pará city, in the Amazon area, it had been, ever since its creation, in the margins of the phonographic business of the great center-south axis of Brazil. Even though the band's musical profile could easily be incorporated into the line of marketing productions of the larger labels, Calypso at first did not get the attention of the mainstream circuit. All the corporate structure that kept the band was built around a cultural movement that used the digital technologies in an economic circuit that was completely autonomous, distributed between the homemade production of CD's, the parties, the characteristic balls and shows of the North and Northeast regions of Brazil as well as the sales of clothing, food, drinks and others ${ }^{5}$ (Dias, 2010, p. 14).

It is possible to say, in this sense, that almost the entire featured circuit is produced "in the garage", by means of lateral marketing. Even though the city of Belém is geographically distant from a supposed phonographic mainstream, it managed to establish a very specific relation to technology, which contributed to the rising of tecnobrega and bregapop as digitally originated phenomena, independent of labels and big studios:

The piracy middleman goes from one house to the other picking up the MP3's that the street vendor is going to sell. If the song gets popular in the street market, it will be played in the ball and will render the artist more concerts. At the party, the latter shouts out to the people at the neighborhood, the concert is recorded live and at the exit it is already on sale. People buy it because were quoted. (Gannan quoted in Dias, 2010, p. 14)

Groups like Calypso question several practices that involve live performances and the sale of records produced in an alternative circuit, which is directly linked to specific forms of cultural producing and releasing. In this "independence or death" scenario, the

\footnotetext{
${ }_{4}^{4}$ For more information on the group's trajectory and the musical circuit where it came from, consult http://www.bregapop. com/sequencias?catid=52\&id=52:tecnobrega-a-musica-paralela-hermano-vianna

5 The drummer Uirá Bueno, another one of my interlocutors in field work, would remember others "artists more involved in mainstream (...) that started this pioneering process of selling their own CDs", as the singer Agnaldo Timóteo. According to Bueno, Timóteo "set up his own stand in Rua da Carioca [Rio de Janeiro' downtown] and sold for a fair price".
} 
concerts begin to appear in a central spot within the cultural repertoire, in the sense that they trigger the musicians' work, especially when the record and physical medias tend to lose their centrality inside the phonographic industry production process (Dias, 2010, p. 16).

The singer Luiz Guilherme, another musician interviewed during fieldwork, emphasizes that the "cultural industry was built over myths that were very present in the 50's and 60's". Co-founder - with Paulinho Moska and Luiz Nicolau - of the rock band Inimigos do Rei $i^{6}$, which exploded in the phonographic scene of the 1980's, he states: "that's what is dying (...) and transforming into something else". After all, in his vision, it is not possible to compare, for instance, the current labels to the ones that operated in the past, which meets Roberto Menescal's - an important musician and producer which I also interviewed - arguments: "it is ending (...), it is not affordable anymore (...). It is a decaying process: in three or four years what we knew as a label will be gone. What is next I don't know".

The observations made by the aforementioned characters mark the existing changes in the big labels' way of acting, which does not invalidate their significant strength inside the market. Menescal continues: "I'm not here to say that Som Livre is about to go bankrupt because it takes advantage of the Globo [Network] thing ${ }^{7}$, but it is getting difficult (...). They are leaning against religious records and, how do you say, in sertanejo's records, gospel, because that's what Brazil looks like". Authors such as Dias (2010) and Herschmann (2010) could certainly complement these considerations. After all they indicate that the development of cellphones and the expanded setting off of their sales play a relevant role in the musical production of the $21^{\text {st }}$ century, taking into account that they offer new possibilities of music consumption.

In her turn, Gabriela Hermanny - a publicist whose career is linked to phonographic sector companies ${ }^{8}-$, observes that there is a great distention in the music industry since, at the same time that the physical media sales subsist, the virtual commercialization of pirate products increases, as well as the official free downloads made available by the digital distributing companies. This interlocutor indicates that the big companies are reorganizing themselves in order to obtain gains from a new kind of commerce: the market has finally realized that the "physical sales are dropping" and that the "digital market is growing on a $30 \%$ average" ${ }^{9}$, concomitantly to piracy, which first came up "when the digital music arose".

To Hermanny, "people only started to consume when the players [companies] got structured", because, up until then, the pirates had crushed the big companies and

\footnotetext{
${ }^{6}$ The band's trajectory is analyzed from the point of view of its members in Wainer (2016a, 2016b).

7 The Som Livre label is the phonographic sector of Rede Globo, the main television network in Brazil.

${ }^{8}$ Hermanny was an employee of Som Livre's Marketing Department and currently works at Vevo, a joint venture responsible for the production of music videos and other forms of digital entertainment. She works at the company's digital distributing section.

9 Several stories published in the media support the argument above. An example http://epocanegocios.globo.com/Informacao/Resultados/noticia/2015/04/vendas-mundiais-de-musica-digital-alcancam-fisicas-pela-primeira-vez.html
} 
people listened to the songs free of charge through the exchange of digital files and the internet. The mentioned structuring, thus, has mostly to do with the industry's perception that they had to find a way to oblige people to pay for the musical content listened to, digitally. In other words, the reorganization of the phonographic market has basically worked in the direction of trying to stop music from being gratuitously consumed, as I have previously demonstrated (Wainer, 2016a).

In this context, many platforms appear offering streaming services, which, becoming increasingly popular, have significantly contributed to the piracy controlling, in the sense that they allow for the decrease of the number of illegal downloads. The totally free services, however, harm the digital products sales, generating a lot of complaints on behalf of the big phonographic companies, which benefit the most from the sales ${ }^{10}$, and also on the behalf of the artists - who end up without the copyrights that would result from the execution of their songs. In the United States, for instance, characters like Joanna Newsom - a singer, songwriter, harpist and pianist - have positioned themselves against free streaming, claiming that it hampers the financial return from royalties - the copyrights - in the same way as the industry had always done"1.

Other artists, however, relativize the opinion above, when they emphasize that the pirate commerce, as well as the digital sales, much as the record sales of the past, might have never given such a big return to them, directly, as it may look like to someone not looking closely. The phonographic recording sales tend to better function in terms of diffusion of the work done by the artists than properly on giving a financial counterpart. Dias (2010) and many artists interviewed defend this point of view, while stating that, in fact, the artist's class earns money mostly from concerts.

As an example, I evoke something said by another one of my interlocutors in fieldwork, the trombone player Fabiano Segalote. When I asked him if there is any financial return for the most of musicians, either through concerts or CD sales, I got the following reply: “nowadays, artists don't earn money from record sales. Piracy is out there, isn't it? How long ago did you buy your last CD?". In the same train of thought, the aforementioned singer Viviane Godoi would put it like this: "I believe that the artists in the past had a longer contract with the label, and a percentage on the record sales. Some royalties (...), which were not much". In her words:

[Gilberto] Gil himself, Caetano [Veloso], all these folks did not make money from record sales. When Gil recorded [the album] Realce, in the 80's, he made a lot of money with the concerts, because the percentage that the label gave him was very small. And these older ones, Orlando Silva, Cartola, these guys didn't earn anything. (Interview to Viviane Godoi)

The singer can firmly attest this because she worked with Gil during the launching of the mentioned record. She would even suggest that "they earned like $2 \%$ record

\footnotetext{
${ }^{10}$ Retrieved from http://canaltech.com.br/noticia/musica/streaming-de-musica-diminui-pirataria-mas-tambem-reduz-vendas-digitais-51819/

"Retrieved from http://g1.globo.com/tecnologia/noticia/2015/10/spotify-e-uma-cabala-vil-de-grandes-gravadoras-dizjoanna-newson.html
} 
sales", which relates to something said by another one of my "natives", the bass player Keko Calazans. According to him, "actually, the ones who made money with record sales were really the label", which means that "only the top artists could reach a percentage such as $10 \%$ of the sales. Roberto Carlos, for instance". He brought to mind a personal situation as a way to illustrate his words:

when we went to SuperStar ${ }^{12}$, the bands - 40 bands! - signed contracts with Som Livre and they had a year to fulfill the contract (...). We couldn't come up on Record [another television channel], we couldn't come up on TV without telling them. In the contract we received $7 \%$ of each record. (Interview to Keko Calazans)

All these observations made on the financial retribution of the musicians in those times show the complexity of a market in which large companies invest a lot of money Viviane Godoi remembers that "the labels spent 500, a million Reais [Brazilian medium of exchange] to put a record out" - in their artists hoping to receive a non-guaranteed financial return. After all, people didn't know whether or not that launch would achieve the expected success. Maybe because of that, the low percentage offered to musicians for their recordings can be explained, as well as the fact that the financial return comes to them in the shape of performed concerts income - considering that the reality of every artist was and still is that one.

\section{BY WAY OF CONCLUSION: RUPTURES AND CONTINUITIES}

The digitalizing process of many medias and equipment has significantly altered the functioning of the phonographic business. This movement has been associated, for the past years, to the advance of piracy and to the development of the internet, which greatly affects the power relations established in the Brazilian record industry along the last century. Old players - the main companies in the field - seek to adapt and try to deal with a reality in which independent paths become possible and really work out, as it happened to Calypso, a successful case that is less and less rare, and other bands. Such considerations form the broader context of piracy development, digital commerce and the interlocking of independent/mainstream production and distribution spheres as important marks of rupture in the artistic and musical scenario of the last decades.

While the rearrangement of a market strictly connected to technology and communicative practices is aligned to a new interactive and participative era, such as Amaral (2012) and Noronha e Sousa et al. (2012) say, one cannot lose sight of some continuities as well. It suffices to recall, for instance, that the maintenance of strategies adopted by large labels since the 1980's - rationalization, segmenting, standardization and pasteurization of the productions - as well as the permanence of some genres as sales records

\footnotetext{
${ }^{12}$ It is a TV show, transmitted by Rede Globo, which premiered in 2014. It resembles the old, important Brazilian music festivals that took place in the 1960's, because it is based in live band performances and in evaluations made by a jury. Currently, however, the public votes in their favorite bands through a smartphone app in real time.
} 
in the Brazilian context, amongst which: the sertanejo and the romantic pop, mentioned by various sources - are still a reality. On top of this, one should consider the controversy on the question of copyrights and on the compensation earned by artists, something that seems far from being solved by the agents linked to the music industry.

If, on the one hand, these transformations produce opportunities for substantial changes, on the other they provoke the need to punctually adjust, especially with respect to this last question. Should the law, considering the cultural digitalizing process, regulate the phonographic market? Who would the regulation of the copyright law benefit the most: large companies, consecrated artists or artists on the onset of their careers? How to make the phonographic industry a more egalitarian environment to the different actors that work in it? Within the next years, what could an artistic market being transformed by phenomena such as the "convergence culture" or the "media convergence", observed by so many researchers (Ganguin \& Hoblitz, 2012; Noronha e Sousa et al., 2012; Piñeiro-Otero \& Ribeiro, 2015), aspire to?

I hope that this article has answered or tried to shed light on some of these matters and that it can, thus, contribute to a better positioning by people who are interested in this debate, or even to the clarification of future concrete actions of the agents that are a part of the musical field.

\section{ACKNOWLEDGEMENTS}

This article is based on original material from my master's degree thesis Digitalization trajectories: musicians and materials in the sociotechnical networks of the Brazilian phonographic industry. I appreciate Coordenação de Aperfeiçoamento de Pessoal de Nível Superior (Capes, Ministério da Educação) financial support granted between 2014 and 2015, without which this research could not have been accomplished.

\section{Translated by Fernanda de Azevedo Pizarro Drummond}

\section{BIBLIOGRAPHIC REFERENCES}

Abreu, P. (2009). A indústria fonográfica e o mercado da música gravada - histórias de um longo desentendimento. Revista Crítica de Ciências Sociais, 85, 105-129. doi: 10.4000/rccs.356

Amaral, I. (2012). Participação em rede: do utilizador ao "consumidor 2.0" e ao "prosumer". Comunicação $e$ Sociedade, 22, 131-147. doi: http://dx.doi.org/10.17231/comsoc.22(2012).1278

Campanelli, V. (2012). Remix it yourself. A do it yourself ethic. Comunicação e Sociedade, 22, 8-15. doi: http:// dx.doi.org/10.17231/comsoc.22(2012).1271

Christiansen, M. (1995). Cycles in symbol production? A new model to explain concentration, diversity and innovation in the music industry. Popular music, 14(1),55-93. doi: http://dx.doi.org/10.1017/ So261143000007637 
Dias, M. (1997). Sobre mundialização da indústria fonográfica. Brasil: anos 70-90. Master's thesis, Campinas State University (IFCH/UNICAMP), Brazil. Retrieved from http://www.bibliotecadigital.unicamp.br/ document/?code $=000120831$

Dias, M. (2000). Os donos da voz: indústria fonográfica brasileira e a mundialização da cultura. São Paulo: Boitempo.

Dias, M. (2010). Indústria fonográfica: a reinvenção de um negócio. In C. Bolaño, C. Golin \& V. Brittos (Eds.), Economia da Arte e da Cultura (pp. 165-183). São Paulo: Itaú Cultural.

Fenerick, J. (2004). A ditadura, a indústria fonográfica e os 'Independentes de São Paulo nos anos 70/80'. Métis: História e Cultura, 3(6), 155-178. Retrieved from http://www.ucs.br/etc/revistas/index.php/metis/ article/viewArticle/1164

Ganguin, S. \& Hoblitz, A. (2012). Mobile Media - Mobile Creativity? Comunicação e Sociedade, 22, 33-48. doi: http://dx.doi.org/10.17231/comsoc.22(2012).1273

Herschmann, M. (2010). Indústria da música em transição. São Paulo: Estação das Letras e Cores.

Hesmondhalgh, D. (1996). Flexibility, post-Fordism and the music industries. Media, Culture Q Society, 18, 469-488. doi: 10.1177/016344396018003006

Noronha e Sousa, M.; Zagalo, N. \& Martins, M. (2012). "Eu também posso propagar histórias". A adaptação e as narrativas transmediáticas na era da participação. Comunicação e Sociedade, 22, 167-183. doi: http:// dx.doi.org/10.17231/comsoc.22(2012).1280

Paiano, E. (1994). O berimbau e o som universal: lutas culturais e indústria fonográficanos anos Go. Master's thesis, University of São Paulo (ECA/USP), Brazil.

Piñeiro-Otero, T.\& Ribeiro, F. (2015). Mobilidade da rádio na era digital: interatividade, participação e partilha de conteúdos nas emissoras ibéricas. Comunicação e Sociedade, 28, 271-289. doi: http://dx.doi. org/10.17231/comsoc.28(2015).2281

Théberge, P. (1989). The sound of music: technological rationalization and the production of popular music. New Formations, 8, 99-111. Retrieved from http://www.sfu.ca/cmns/faculty/marontate_j/386/o6-fall/ Readings789/Theberge1989.pdf

Vicente, E. (1996). A música popular e as novas tecnologias de produção musical. Master's thesis, Campinas State University (IFCH/UNICAMP), Brazil. Retrieved from http://www.bibliotecadigital.unicamp.br/ document/?code=000107977

Vicente, E. (2002). Música e disco no Brasil: a trajetória da indústria nas décadas de 80 e 90. Doctoral thesis, University of São Paulo (ECA/USP), Brazil. Retrieved from http://www.abpd.org.br/wp-content/ uploads/2015/01/doutoradoEduVicente.pdf

Vicente, E. (2008). Segmentação e consumo: a produção fonográfica brasileira, 1965-1999. ArtCultura, 10(16), 103-121.

Wainer, D. (2016a). Trajetórias da digitalização: músicos e materiais nas redes sociotécnicas da indústria fonográfica brasileira. Master's thesis, Federal University of Rio de Janeiro (PPGAS/MN/UFRJ), Brazil.

Wainer, D. (2016b). Um olhar antropológico sobre as transformações da indústria fonográfica brasileira

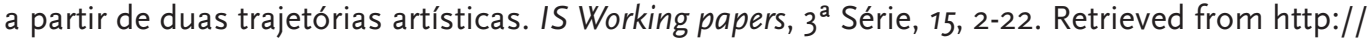
isociologia.pt/App_Files/Documents/wp15_160219102112.pdf 


\section{BIOGRAPHICAL NOTE}

Daniel Ferreira Wainer is a doctorate student in the Post-Graduation Program of Social Anthropology at the National Museum, Federal University of Rio de Janeiro (PPGAS/ MN/UFRJ). He has a Master's degree in Social Anthropology at the same institution and an undergraduate degree in Social Sciences at the Philosophy and Social Sciences Institute of the Federal University of Rio de Janeiro (IFCS/UFRJ). He is also a musician, having recorded the album Associação Livre with the group Sararás Livres. Since 2014 his reseach interests have been focusing on sociotechnical transformations in the Brazilian music industry and broadly in an Anthropology of Music.

E-mail: danielfwainer@gmail.com

Almirante Saddock de Sá Street, 40/303, Ipanema, 22411-040 Rio de Janeiro / RJ, Brazil

* Submitted: 15-10-2016

" Accepted: 23-01-2017 